\title{
Study on International Market Entry Mode of Beijing High-tech Enterprise
}

\author{
Diao Yi \\ College of Civil and Enginerring, College of Economics \\ and Business Administration \\ North China University of Technology \\ Beijing, China \\ diaoyi129@163.com
}

\author{
Tianyong Niu \\ College of Civil and Engineering, College of Economics \\ and Business Administration \\ North China University of Technology \\ Beijing, China
}

\begin{abstract}
The success of Beijing high-tech industry internationalization strategy greatly affects the high-tech enterprises in the whole country, and even the national economy. The paper analyzes the international market status of Beijing high-tech enterprises to find the main factors affecting the international market entry mode in terms of environment of host countries, domestic environment and environment of the enterprises, which is a good reference to Beijing high-tech enterprises to choose the proper international market entry mode.
\end{abstract}

Keywords-Beijing high-tech industry,international market entry mode, affecting factor

\section{INTRODUCTION}

High-tech industry plays an important role in promoting the capital's economic and social sustainable, rapid and coordinated development, and developing high-tech industry is the crucial way of enhancing comprehensive competitive power of capital economy and optimizing the industrial structure. As the capital of Chinese software industry, Beijing has become the national information service center, the most important research and development base and one of the most important telecommunication hubs in the Asian-Pacific region. In the "Eleventh Five-Year" period, Beijing focused on developing high-tech service industry, electronic information industry and biological industry, achieving the targets of scale growth, structural optimization, power ups and industrial agglomeration. High-tech industry becomes the economic pillar industry of the capital and strategic high ground of Chinese high-tech industry. The success of Beijing high-tech industry internationalization strategy greatly affects the high-tech enterprises in the whole country, and even the national economy. Thus, the paper takes Beijing high-tech industry as research object, and studies the influencing factors of international market entry mode intensively to assist the international operation of Beijing high-tech enterprise.

\section{INTERNATIONAL MARKET ENTRY MODE OVERVIEW}

International market entry mode is an important component of enterprise's internationalization strategy. The correct choice of international market entry mode is the decisive factor key to the success of internationalization strategy. The research on international market entry mode starts with international investment theory. Presently the field mainly includes five basic theories while other theories are the extensions and expansions based on the five ones.

\section{A. Developing Stage Theory}

Johanson and Paul put forward the developing stage theory when they study the internationalization strategy of small and medium enterprises. In the developing stage theory, the enterprise internationalization is a slow, long-term and gradual stage, being developed in two directions-foreign markets geographical positions and resources input. And enterprise should choose the international market entry mode that suits with the development stage. At the initial stage of internationalization, enterprise prefers to choose suitable place with less resource input close to motherland. With the accumulation of international business experience, enterprise will input more resources gradually and prefer to run business in the markets with bigger psychological distance. Developing stage theory underlines that the enterprise internationalization is a dynamic process. However, with the rapid development of information technology, economy and acceleration of globalization, the theory can't explain the phenomenon that some new enterprises establish solely foreign-owned enterprise directly instead of using the import way.

\section{B. Transaction Cost Theory and its Extension}

Andeson and Gatignon(1986)proposed the transaction cost theory of international market entry mode based on the transaction cost economics theory of Williamson. The theory holds that the choice of international market entry mode is restricted by transaction cost, so enterprise will choose the entry mode with long-term maximizing efficiency, which depends largely on trading asset specificity, internal and external uncertainty as well as the optimal control degree. According to the theory, the higher the asset specificity and the more stable the internal and external environment, the enterprises are more likely to apply investment with higher control degree to enter the international market. Afterwards, more scholars perfect and expand the theory. And environment, strategy and cost of production are introduced into the model. Nevertheless, the transaction cost theory has the "birth defect", for examples, some variables are difficult to measure; less theoretical factors and more restrictions are considered; the enterprise can't be considered as a whole. 


\section{Eclectic Theory}

Dunning(1977)raised the eclectic theory to illustrate and evaluate the initial behavior and development of overseas production. In the subsequent decades, he expanded the theory constantly. The eclectic theory holds that international market entry mode of enterprises are mainly decided by three factors which are ownership advantage, internalization advantage and location advantage respectively. According to the theory, the enterprise with the above three advantages is inclined to adopt investment way to enter the market; the enterprise in the lack of location advantage only adopts export trade way; the enterprise with only ownership advantage can operate by the transfer of technology. In a word, eclectic theory model is widely used and supported by empirical data. However, the theory tries to affect all the important factors of market entry mode, but neglects the enterprise strategy, contingency factors around the decision maker and the competition.

\section{Organization Ability Theory}

Based on organization theory, Aulakh, Kotabe(1977)and Madhok proposed the organization ability theory which holds that enterprise is the complex of various knowledge and abilities, such as personal skills, organization and technology. The correct choice of enterprise market entry mode can transfer and make good use of resources effectively. In the theory, the organizing ability is introduced into consideration of choosing the international market for the first time. It considered that if the enterprise resources and abilities have specificity, the enterprise will enter the market in a whollyowned way for avoiding being mimicking or replicating. The enterprise in the lack of resource will enter the international market by acquisitions or joint venture. But the theory neglects the role of organizational efficiency which has an effect on organizing ability.

\section{E. Organization Ability Theory}

Root (1994) is the first one who proposed decision process theory. He considered that the enterprise market choice is a multi-stage decision-making process. In the process, the enterprise should take target market, existing environment and related costs and risks into account, and focus on the optimum of decision-making process rather than only considering the factors effecting market entry mode. Actually, the theory is more practical and effective, but it neglects organization and decision maker' roles in decision making process.

\section{The International Market SELECTION STAtus of BEIJING HIGH-TECH ENTERPRISE}

There had been 1150 high-tech enterprises and 238984 employees in all in Beijing by 2009. The output value is 275.414 billion yuan and profits is 15.65 billion yuan; and Beijing has ranked the fifth one after Guangdong, Jiangsu, Shanghai and Shandong. In 2009, high-tech products export reached 17.52 billion USD, accounting for $36.2 \%$ of the total export volume. It's thus clear that high-tech products occupy a large proportion in exports. At present, Beijing high-tech enterprises still considers export as the primary international way in the international operation process.

\section{A. Locational Choice}

In 2009, the Beijing high-tech products were exported to EU, Hong Kong and America which are top three areas, followed by ASEAN, Japan and South Korea whose export amount was far less than the above three countries and regions. Thus, the export areas of Beijing high-tech products mainly focus on developed countries and regions or countries and regions close to China geographically. Beijing high-tech enterprises usually aim at European and American markets with advanced technology when adopting contract mode to enter international market.

\section{B. Industry Choice}

In terms of industry choice, the exports of computer network and communication technology came out top in Beijing high-tech industry exports, making up 75\% of the hightech products exports and being the main force of Beijing hightech industry products exports. Electronic technique was ranked second, making up approximately $12 \%$. That is to say, the Beijing high-tech products exports give priority to computer, communication and electronic technique, supplemented by aerospace engineering, life science and technology, as well as computer-integrated manufacturing technology.

\section{Management Mode Choice}

At present, most of Beijing high-tech enterprises choose export mode for entering overseas market. In recent years, with the economic development and constant strengthening of hightech enterprises, international business management mode of Beijing high-tech enterprises presents diverse tendencies. Some high-tech enterprises, led by Huaqi Information and UFIDA start to set up distribution channels and production bases outside the country. Some high-tech enterprises, led by Baidu and PWRD, begin to be listed on overseas stock markets in financing. And some high-tech enterprises, led by Lenovo and BOE, take over overseas companies for merger to obtain core technology.

\section{The FACTORS AfFECTING ThE INTERNATIONAL MARKET CHOICE OF BEIJING HIGH-TECH ENTERPRISES}

\section{A. The Environment of Host Countries}

1) The Marketing Environment of Host Countries

The marketing environments of host countries play an important role in internationalized operation and choosing the appropriate market entry mode, which is always the focus of theory field. Karakey and Stahl listed 19 environmental factors of host countries affecting the international market entry mode in the article, based on which other scholars pointed out that market size, government policy, geography and infrastructure of host countries can also affect international market entry mode of enterprises. Combining the characters of high-tech enterprises, the author considers that the marketing environment of host countries affecting the international 
market entry mode of high-tech enterprise mainly includes the following respects. (1)The market capacity of host countries. Scholars researched to find that market capacity is an important influencing factor when choosing the overseas business mode. The enterprise prefers to enter the market of countries with high market capacity by investment mode which can let the enterprise makes good use of economies of scale to lower marginal production costs and obtain a higher income, compared with contract mode or trade mode. (2)The market structure of host countries. If the competition structure of target market is oligopoly type or monopoly type, the enterprise should consider entering the market by contract mode or investment mode to compete with the powerful local enterprises. If the market structure of target market is dispersive, enterprise should choose export mode because the market has lower profit level. If enterprise chooses investment mode to input too much resource, they will make no profits. (3) Factor market condition of host countries. It mainly means production factors of host countries in terms of raw materials, labor force and energy sources. When the cost and quality of production factors have comparative advantage, compared with those of the own country, the enterprise is usually more willing to choose investment mode to enter target market. On the contrary, the enterprise will choose trade mode or contract mode.

2) The Political, Economic, Legal and Cultural Environment of Host Countries

Root (1987) pointed out that international market entry modes will be affected by four types of country risks including political risk, ownership risk, and operational risk and transferring risk. Country risks mainly mean that existing economic and political environment of host countries, the uncertainty of government policy and government policy changes may lead to the profit problems, and even the problem of asset collection. The enterprise is not willing to enter the market of countries with high country risks for it's hard to exit without anything lost. Moreover, the scholars' research shows that restrictive policy of host countries will deter international capital from flowing to the country. So enterprise is reluctant to enter the markets of above countries or adopt low-risk mode to enter the market. However, referring to the countries with more stable political system, economic policy and legal environment, enterprise tends to enter the market by investment mode.

Psychical distance means the factors hinder or interfere with information flow between enterprise and market, including language, culture, political system, educational level and economy development phase, which were firstly proposed by W.Beckerman in the paper. Based on the concept, North European scholars analyze and reveal the sequence when enterprise chooses international markets. Namely, it choose according to psychical distance, from the near to the distant. North European school of thought considers that enterprise gives preference to the countries with politics, economy, cultural background and market conditions similar to those of their own countries.

\section{B. Domestic Environment}

Domestic environment mainly contains domestic market scale, market structure, factor market conditions and government policy. When domestic market scale is large, enterprise will give preference to domestic market rather than overseas market for the big growth space of enterprises. When domestic market is oligopoly or monopoly, enterprise will choose investment mode to enter overseas market for competition based on their competitive advantage. In addition, if domestic factors market has no comparative advantages, comparing with the market of host countries, the enterprise will choose investment mode to enter overseas market. Finally, domestic government policy will also influence international market entry mode greatly.

\section{The Environment of the Enterprises}

\section{3) Enterprise Scale}

The result of investigating indicates that there are positive correlations between enterprise scale and FDI. In other words, the enterprises with bigger size are more likely to adopt joint ventures or wholly-owned mode with higher control degree beyond the sea (Yu and Ito 1988, Kimura1989). The scholars, such as Leung (2003) also argue that enterprises with bigger scale are more likely to apply the way of securities to enter market instead of export or other ways. Kuo and Li (2003) considers that comparing with major industry, medium-sized and small enterprises are far less superior in terms of resources, anti-risk capability and cost reduction, so they tend to adopt export mode.

\section{4) International Experience of Enterprise}

International experience of enterprise plays a decisive role in selecting target market and entry mode, being always emphasized in theory research. The so-called international experience means how much enterprise knows about and masters the foreign political, economic, cultural and market environment. International experience usually comes from employees living, working and learning experience abroad or enterprise actual operation in local market (Reuber and Fischer). When enterprises are in the lack of international experience, they should choose the international market similar to domestic market or adopt indirect export mode. Otherwise, entering unfamiliar international market rashly may bring huge bosses to enterprises. The result of investigating indicates that enterprises lacking international experience may encounter more problems when operating abroad. Thus, enterprises lacking of international experience usually choose trade or contract way to enter international market while enterprises with international experience usually prefer to adopt investment way or strategic alliance way (Delios and Henisz, 2003; Erramilli1991).

\section{5) Product Factors of Enterprise}

When comparing with overseas market products, the domestic products has no big comparative advantage, enterprise tends to enter the market by producing locally. That's because trade mode may result in no profits when additional cost factors, such as transportation cost and import tariff are considered. Referring to the products with 
comparative advantage, enterprise prefers to enter international market through trade way.

In addition, with respect to technology content, the products of high-tech enterprise contains a lot of proprietary technology, so enterprise usually chooses wholly owned way with high control power rather than joint venture and contract mode for entering foreign markets to lest proprietary technology outflow. However, refer-ring to the labor intensive products and resource intensive products, enterprise usually prefers to choose trade way or contract mode to enter international market.

\section{6) Strategic Factors of Enterprise}

The enterprise adopting multi domestic strategy in the overseas business process considers that the markets, consumer preferences, competitive environment, production condition as well as political, economic and le-gal environment are different so enterprise should adopt various competitive strategies to enter the markets with lower cost. Meanwhile, not too much control power is required, so the enterprise is apt to enter international markets through license way or joint venture. On the contrary, the enterprise adopting global strategy tends to use the individual proprietorship way with higher control power.

In conclusion, the paper analyzes the international market status of Beijing high-tech enterprises to find the main factors affecting the international market entry mode in terms of environment of host countries, domes-tic environment and environment of the enterprises, which is a good reference to Beijing high-tech enterprises to choose the proper international market entry mode. However, the paper doesn't study the importance of the factors deeply or how the factors play a role in deep analysis, which are the research directions in the near future.

\section{ACKNOWLEDGMENT}

This work was supported by a grant from the Research Fund for the scientific plan by Beijing Municipal Commission of Education (No:KM201610009010)

\section{REFERENCES}

[1] MalhotraNK,Agarwal J,UlgadoFM. 2003. Intemationalization and Entry Modes: A Multitheoretieal Framework and Researeh ProPosition. Journal of International Marketing, 11(4) : 1-31

[2] PanY,Tse DK. 2000. The Hierarchical Model of Market Entry Modes. Journal of International Business Studies, 31(4) : 535-554.

[3] Ranft AL,Lord MD. 2000. Acquiring New Khowledge:The Role of Retaining Human CaPital in Acquisitions of High - tech Firms.Journal of High Technology Management Research,11 (2): 295 - 319.

[4] Shane SA,Ulrich KT. 2004. Technological Irmovation,Product Development and Entrepreneurship in Management Seience, ManagementScience,50(2): $133-144$.

[5] Andersen, O. 1993. On the Internationalization Process of Firms: a critical analysis, Journal of International Business Studies, 2: 209-231.

[6] Anderson, E and H.Gatignon,(1986). Modes of Foreign Entry: a Transaction Cost Analysis and Propositions. Journal of Interrnational Business Studies, 17(1):1-26.

[7] Jane W. Lu. 2002. Intra-and Inter-organizational Imitative Behavior: Institutional Influences on Japanese Firm's Entry Mode Choice. Journal of International Business Studies , 33(1):19-38.

[8] Keith D.Browthers. 2002. Institutional, Cultural, and Transaction Cost Influences on Entry Mode Choice and Performance. Journal of International Business Studies,33(2): 203-222. 